\title{
Bir kültür ekonomisi dönüşüm serüveni: ‘okuntu’dan ‘e-davetiye’ye'
}

\section{İbrahim GÜMÜȘ²}

\begin{abstract}
APA: Gümüş, İ. (2019). Bir kültür ekonomisi dönüşüm serüveni: 'okuntu'dan 'e-davetiye'ye. RumeliDE Dil ve Edebiyat Araşturmaları Dergisi, (15), 227-241. DOI: 10.2900o/rumelide.580512
\end{abstract}

\section{$\ddot{O} \mathbf{z}$}

Kültür, insanın yaşamına ve doğaya kattığı geniş sistemler bütünüdür. Kültürün bir parçası olan doğum, ölüm, sünnet, evlilik gibi geçiş dönemleri bireylerin toplumsallaşmasında, kendi aralarında ilişki kurmalarında ve aile yapılarının kuvvetlenmesinde önemli bir işlevi vardır. Küreselleşme ve sanal ortamla birlikte iletişim hızlı ve kolay bir biçimde yapılmaktadır. Bu durum kültürel ürünlerin üretim, sunum ve tüketim biçimlerini hızla etkilemekte ve dönüştürmektedir. Kültür endüstrisi fikri mülkiyet haklarınca korunan kültürel ürünlerin üretim aşamasından tüketimine kadar geçen ekonomik faaliyetler bütünüdür. Türk toplumunda önemli bir geçiş ritüeli olan düğünün başlangıcını haber verme, düğüne davet etme anlamlarına gelen "okuntu” geleneği pek çok kültürel kodu içerisinde barındırır. Anadolu'da düğüne sözlü olarak davet etme işini yapan kişiye "okuyucu”, davet işlemi sırasında dağıtılan hediyeye veya davet etmek için yazılı kağıda "okuntu” adı verilir. Okuntu geleneği, yazılı kültür ortamının yaygınlaşmasıyla ilk olarak yerini dügün davetiye kartlarına bırakmaya başladı. Okuntu geleneği, düğün sahibine biraz pahalıya mâl olduğundan bu geçiş bir noktada ekonomik nedenlerle gerçekleşmiştir. Davetiyelerin ortaya çıkışıyla okuntu geleneğinde olduğu gibi kumaş, çorap, şeker gibi hediyelerin verilmesi ortadan kalkmıştır. Türk toplumunun genelde elektronik kültür ortamı özelde ise sanal kültür ortamına geçişi okuntu geleneğinin icrasını ve sunum biçimini değiştirmiştir. Okuntu geleneği bu etki ve dönüşüme maruz kalarak önce “davetiye”ye, sonra “e-davetiye”ye dönüşmüştür. Bununla birlikte değişim, yeni bir kültürel ekonomik alan yaratmıştır. Bu makalede okuntudan e-davetiyeye geçiş sosyo-kültürel açıdan ve kültür ekonomisi bağlamında irdelenecektir.

Anahtar kelimler: Kültür ekonomisi, düğün, okuntu, e-davetiye.

\section{Adventure of a cultural transformation economy: e-invitation from okuntu}

\begin{abstract}
Culture is a collection of large systems that man has added to his life and to nature. The transition periods, such as birth, death, circumcision and marriage, which are part of culture, have an important role in the socialization of individuals, in their relations and in the strengthening of family structures. Communication with globalization and virtual environment is carried out quickly and easily. This rapidly impacts and transforms the production, presentation and consumption of cultural products. The cultural industry is a collection of economic activities that take place from production stage to consumption of cultural products protected by intellectual property rights. The "read" tradition, which means to inform and invite the beginning of the wedding, which is an important rite of passage in Turkish society, contains many cultural codes. In Anatolia, the person who does the job of verbally
\end{abstract}

I. Ulusal Genç Halkbilimciler Sempozyumu'nda (Balıkesir, 10 Kasım 2012) sunulan sözlü bildirinin genişletilmiş biçimidir.

2 Dr. Öğr. Üyesi, Bartın Üniversitesi, Edebiyat Fakültesi, Türk Dili ve Edebiyatı Bölümü, (Bartın, Türkiye), ibrahimgms@hotmail.com, ORCID ID: 00oo-0002-6033-0234 [Makale kayit tarihi: 12.03.2019-kabul tarihi: 16.06.2019; DOI: $10.29000 /$ rumelide.580512] 


\begin{abstract}
inviting the wedding is called "reader", the gift distributed during the invitation process, or the written paper to invite them. The tradition of reading began to be replaced by wedding invitation cards with the spread of the written cultural environment. Since the tradition of reading is a bit expensive to the wedding owner, this transition was realized at some point for economic reasons. As in the tradition of reading with the emergence of invitations, giving gifts such as fabrics, socks and candy has been eliminated. The transition of Turkish society to an electronic cultural environment in general and to a virtual cultural environment has changed the practice of the tradition of reading and the way of presentation. The tradition of reading has become "invitation" and then "e-invitation"by being exposed to this effect and transformation. However, change has created a new cultural economic area. The transition e-invitation from okuntu in this article will be examined in terms of socio-cultural and cultural economics.
\end{abstract}

Keywords: Cultural economics, wedding, okuntu, e-invitation.

\title{
1. Giriş
}

Kültür, insanın yaşamına ve doğaya kattığı kısaca maddi veya manevi olarak geliştirdiği her unsuru kapsar ve nesilden nesile çeşitli araçlarla aktarılır. Kültürün bir parçası olan doğum, ölüm, sünnet, evlilik gibi geçiş törenleri bireylerin toplumsallaşmasında, kendi aralarında ilişki kurmalarında ve aile yapılarının kuvvetlenmesinde önemli bir işlevi vardır. Yeryüzünde yaşayan hemen hemen her kültürde bu özel günlerin ayrı bir kültürel oluşumu ve icrası yer alır. E. B. Taylor kültürü, bilgiyi, sanatı, ahlaki, inancı, hukuku, örf ve adetleri bireyin mensup olduğu toplumun bir parçası olması dolaysıyla kazandığı alışkanlıkları ve diğer bütün becerilerini içeren iç içe geçmiş özelliklerin bileşkesi olarak tarif eder (Turhan, 1969: 34). Kültür çalışmaları son on yılda özellikle "kent, ekonomi, tüketim, siyaset, spor" gibi alanlara odaklanmıştır. Kültür ve ekonomi arasındaki ilişki yeni değildir. Tüketim ve kültür arasındaki gelişmeler sosyo-toplumsal yapıda bariz değişikliklere sebep olmuştur. Bu çalışmada teknolojinin gelişmesine bağlı olarak genelde kültürümüzde özelde tüketim kültürümüzde meydan gelen değişimlere bağlı olarak okuntu geleneğinin geçirdiği dönüşüm incelenecektir.

Kültür endüstrisi veya ekonomisi, yaratıcı endüstri olarak da bilinir ve kültürel ürünlerin yaratımından üretimine, dağıtımından tüketimine kadar olan süreçleri ekonomik faaliyet biçiminde sürdüren endüstrinin genel adıdır. Kültürün bir endüstri, kültür ürünlerinin de meta'lar şekline dönüştüğü görüşü kültür endüstrisi kavramının ortaya çıkışına kaynaklık eder. Kültür endüstrisinde, kültür ürünlerinin standartlaştırılarak ve buna karşı farklılıklar marjinalleştirilerek bu ürünlerin tanıtılma ve dağıtım tekniklerinin rasyonelleştirilmesi anlatılmaktadır. Kültür endüstrisi kavramı, 1944 yılında Frankurt Okulu'na mensup Teodor Adorno tarafindan kullanılmıştır. Daha sonra kültür endüstrisi terimi Theodor Adorno ve Max Horkheimer, Aydınlanmanın Diyalektiği adlı eserlerinde kullanıldı. Adorno ve Horkmeimer, kültür endüstrisi kavramını karamsar ve "durmaksızın vaat ettiği şeylerle tüketicisini durmaksızın” (Adorno ve Horkmeimer, 2014: 186) aldatan olumsuz bir yaklaşımla ele alır ve kültürün metalaştırılıp ticari ve endüstriyel bir ürün haline dönüşmesine işaret ettiler.

Kültür ekonomisi, yirminci yüzyılın ikinci yarısında Avrupa'da sanayileşmenin etkisiyle ortaya çıkan kent-sanayi folkloru araştırmalarıyla ilgi görmeye başlar. Kültürün ekonomi ile ilişkisi başlangıçta olumsuz eleştirilerle irdelenir (Özdemir, 2009: 74). Frankurt Okulu temsilcileri tarafından kültür endüstrisi "kitlelerin kandırılması" şeklinde olumsuz bir yaklaşımla incelenir. Onlar, kültürel endüstriyi kültürün metalaştırılması ve tek tipleştirilmesinden sorumlu tutar. Kültür endüstrisi, tüketim toplumunu oluşturmuştur. Bu kitleye daha fazla mal satmak ve onları doyumsuzluğa ulaştırmak kültür 
endüstrisinin temel özelliğidir. Cengiz Yanıklar’a göre çoğu "kültürde, ama özellikle geleneksel toplumların kültürlerinde, ihtiyaçların sınırsız ya da "doyurulamaz" olma olasılığı bile, sosyal ya da ahlâki bir hastalığa işaret ederken, tüketim kültüründe bireylerin sonsuz ihtiyaçlara sahip olabileceği ilkesi” (Yanıklar, 2010: 26-27) kültür endüstrisi içinde yaşayanlar tarafından olağan görülür.

Kültür endüstrisi bu olumsuz yaklaşımların yanı sıra olumlu bakış açllarıyla da ele alınır. Kültür endüstrisi (Fransız yaklaşımı), yaratıcı endüstri (İngiliz yaklaşımı), deneyim ekonomisi (İskandinav yaklaşımı) veya içerik endüstrisi (OECD yaklaşımı) gibi kavramlarla karşılanan kültür ekonomisi günümüzde olumsuzlayıcı yaklaşımlardan sıyrılmış ve bağımsız bir alan haline gelmeye başlamıştır. Kültürel endüstri, teknolojik ve medya gelişmelerine bağlı olarak toplumdaki gelişmelere uyum sağlayarak küresel pazarlara ulaşmak için üretim süreçlerini ve dağıtım yöntemlerini de bünyesine katar. 20. yüzyılın sonlarında ABD ve İngiltere'de yaratıcllı̆̆ ve yeniliğe önem veren yaratıcı ekonomiye doğru evrilir. 1980'lerden sonra ekonomik politikalarda yaşanan değişimlerle birlikte kitle kültürü, marka kültürü Türkiye'de gündeme gelmeye başlamıştır.

Kültür ekonomisi veya kültür endüstrisi gibi terimler elektronik kültür ortamının gelişmesine bağlı olarak toplum yaşamını köklü bir şekilde değiştirmesinin sonucunda ortaya çımıştır. Grupların hızla ikincil kültür ortamı ürünlerine yani "hızla elektronik, sanal ve dijital kültür bağlamlarına geçişi, belirtilen dinamiklerin bir nedeni ve sonucudur. Yeni kültür bağlamları, yeni sistemleri, araçları, ürün ve hizmetlerle aktörleri de beraberinde getirmiştir" (Özdemir, 2009: 75). Sanal ortam tek başına kocaman bir kültürel alan haline gelmiş ve kültür ekonomisinin de temelini oluşturmuştur. Kültür ekonomisi, kültürel kodları farklılaştırmış, bireysel ya da kolektif yaratımı, kuşaktan kuşağa aktarımı ve tüketimi hızla değişmiştir. Ertuğrul Günay’a göre internet yani sanal kültür ortamı sanat eserlerinin "topluma yayılmasını sağlayacak yeni kapılar açmış, hak sahiplerinin tanınmasını ve gelir elde edilebilecek" (Günay, 2010: 9) yeni mecralar oluşturmuştur. Bu nedenle sanal ortam kültür endüstrisinin gelişmesi için önemli bir araçtır. Bununla birlikte dijital ortam, kültürel ürünlerinin yaratılmasındaki emek, zaman, sermaye gibi zorluk süreçleriyle zıt bir biçimde onlara kolay ulaşılabilen bir süreci de yaratmıştır.

Kültür ekonomisinin çalışma alanı sanat alanlarından medyaya, tasarımdan endüstriye, kent kültüründen kültürel mirasa kadar oldukça geniş bir alanı kapsar. Medya, müzik, film, oyun, yayıncılık moda, tasarım endüstrisi, müzeler, galeriler, kültürel ve sanatsal etkinlik mekânları, kültürel miras ve kültür turizmi ve nihayet reklamcılık, halkla ilişkiler, ağ pazarlaması, bilgi teknolojisi hizmetleri, Ar-Ge yönetimi gibi yaratıcı iş hizmetleri bu ekonominin kapsamını, ulaştığı boyutları gösteriyor. Kültürün aynı zamanda bir ekonomi olması onun değerini düşürmüyor. Tam tersine kültürlerin ekonomik değerleri onların iletişim değerlerini ve etki alanlarını artırıyor. Kültür ekonomisi ve alışverişiyle kendi değerlerinizi de dünyaya açıyor ve her ülkeden insanı etkiliyor, kendinize yakınlaştırıyorsunuz (Uçkan, 2009: 1). AB ülkelerinde bu alanda bilinçli ve ciddi çalışmalar yapılmaktadır. Kültür ekonomisi için büyük bütçeler ayrılmakta ve ülkelerin gelirlerinin bir kısmı da buradan sağlanmaktadır. Örneğin, İngiltere'de kültür ekonomisi alanında 2001 yllında 1.3 milyon kişi istihdam ediliyordu ve \% 4.7 yani 15 milyon Euro ihracat geliri vardı. 2017 yılında ise yaklaşık 3 milyon istihdam sağlanıyor ve toplam gelir yaklaşık 100 milyon Euro'ya ulaşmıştır (bkz. https://www.gov.uk). Türkiye'de ise bunun yarısı kadar bir gelir elde edilememiştir. 


\section{Türk kültüründe okuntu geleneği}

Okuntu sözcüğü başlangıçta davet etmek anlamında kullanılırken zamanla anlam daralmasına uğrayarak kelime küçük hediyelerle yapılan düğün daveti olarak kullanılmıştır. Dîvânü Lûgati’t-Türk’te çă̆ırmak anlamında (ol meni okıdı) "okı- (dı/mak)" (Ercilasun ve Akkoyunlu, 2018: 459) ve yemeğe veya saltana davet etmek manasında ise "okut" (Ercilasun ve Akkoyunlu, 2018: 24) sözcükleri yer alır. Kutadgu Bilig'de "negü teg okılım anı ay berü / kimi ıdsa bolgay okıtçı naru (Onu buraya nasıl davet edelim, onu çağırmak üzere kimi gönderelim)" (Arat, 2007: 322) şeklinde geçen kelime "okı" davet etmek, "okıtçı" ise davet işini yapan kişi olarak geçmektedir. Türkler'de eski zamanlarda davete çağırma sembolü olarak "ok" kullanılırdı. Ok sadece toy zamanında değil, savaş ve çeşitli görüşmeler için de kullanılırdı. Oğuz Kağan Destanı'nda Oğuz, ülkeyi oğulları arasında paylaştırma/bölüştürmeyi gümüş "ok”la gerçekleştirir: "Sundular Oğuz-Han'a, Han sevindi, hem güldü. Aldı üç gümüş oku, kırarak üçe böldü” (Ögel, 2003: 127). Destanda ok paylaştırma işleviyle kullanır. Dede Korkut Kitabı'nda yer alan Kam Büre Oğlu Bamsı Beyrek adlı boyda toy sırasında "ok" atılır: "Oğuz zamanında bir yiğit ki ivlense oh atar-idi, oḳı ne yirde düşse anda gerdek diker-idi (Ergin, 2008: 129).” Dede Korkut’ta “ok” toy, dügün evlilik gibi işlerde haber verme işleviyle kullanılmıştır.

Anadolu'da düğüne sözlü olarak davet etme işini yapan kişiye "okuyucu”, davet işlemi sırasında dağıtılan hediyeye veya davet etmek için yazılı kă̆ıda "okuntu” adı verilir. Ali Berat Alptekin (2009: 314), "okuntu" sözcüğünün Anadolu'da davet etmek anlamına geldiğini ve ok atma ile ilişkili olduğunu belirtir. Ayrıca Toroslu Türkmenlerden okunmayan yani okuntu verilmeyenlerin düğün sahiplerine küstüklerini söyler. Okuntu sözcüğü davet etme, paylaştırma, hediye verme, düğün gibi anlamları da bünyesinde barındırmaktadır. Okuntu geleneği, Antalya, Muğla, Elazı̆̆, Eskişehir, Kırşehir, Mersin, Niğde, Sivas (bkz. Koşay, 1944) gibi Anadolu'nun pek çok yerinde yirminci yüzyılın ikinci yarısına kadar yaygın bir şekilde yapılmaktaydı. Şeref Boyraz (2009:89), Sivas'ın bazı ilçelerinde "okuntu” sözcüğü yerine "mumcu" kavramının kullanıldığını da belirtir. Sivas'ta okuntu geleneği şu şekilde yapılır. Düğün hazırlığı içerisinde olan aileler bütün görevlerini mümkün olduğunca yerine getirdikten sonra düğün ve gelin alma tarihi belirlenir. Düğüne çağrllacak kişi listesi aile büyüklerince veya okuryazar olan bir genç ile hazırlanır.

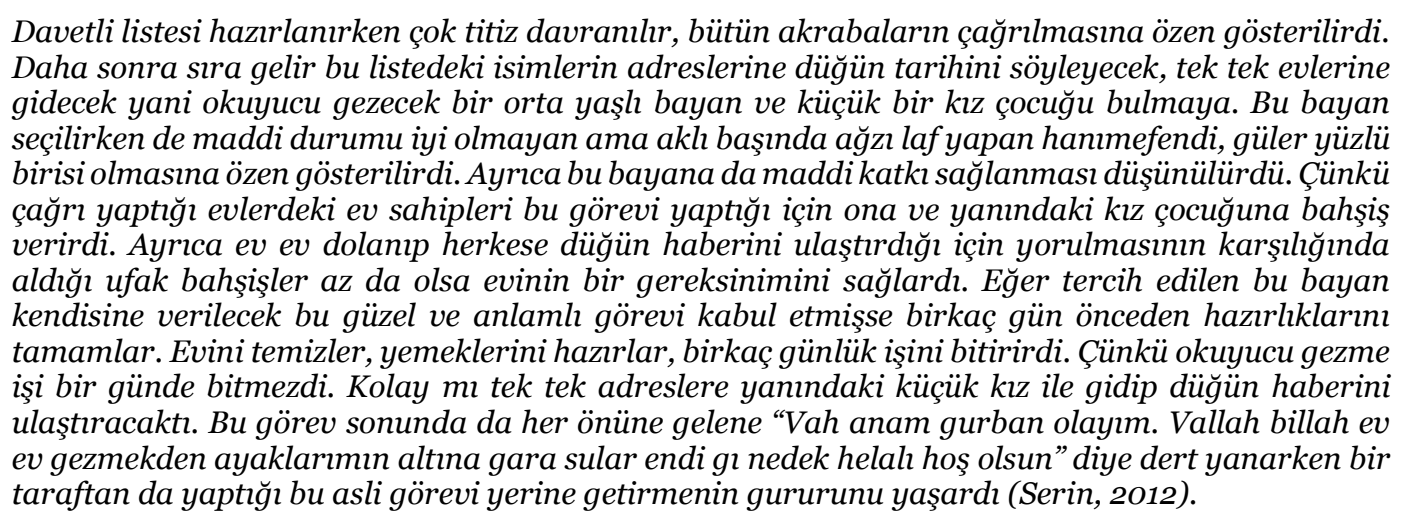

Zamanla bazı bölgelerde "okuntu” işini yapan yani bugünkü marka diyebileceğimiz kişiler oluşmuştur. Bunlar o bölgedeki insanlar tarafından sevilen, oturmasını kalkmasını bilen, güzel konuşan, ekonomik olarak zayıf kişilerdir. Ahmet Urfalı (2012), Emirdağ'da düğün dernek olacağı zaman okuntu denilince akla ilk gelen ismin "Okuntucu Dudu” olduğunu belirtir. Bazı bölgelerde biri kadın diğeri erkek iki farklı "okuyucu” tutulurdu. Erkek okuyucu erkekleri, kadın okuyucu ise kadınları düğüne davet ederlerdi. Kız evinin okuyucu ile gönderdiği hediyelere dürü de denmektedir. Okuyucu ile birlikte dağıtılan hediyeler 
arasında kumaş, havlu, namazlık, bardak, çorap, mendil, şeker, çerez, gömlek, havlu, tülbent gibi eşyalar vardır.

Okuyucu ve yanındaki küçük kız, okuntuya çıkmadan bir gün önce hamama götürülür veya evde banyo yaptırılırdı. Bir sonraki gün en güzel elbisesi ve ayakkabısı giydirilip saçları taranırdı. Hazırlıklar bittikten sonra küçük kızın boynuna bahşiş konması için bir çanta takılırdı. Okuyucunun elindeki davetli listesine göre adresleri gezerdi. Gezme sırasında şunlar yapılırdı:

\begin{abstract}
"Her gittiği evin varsa zilini çalar, yoksa kapının zerzesini (tokmak) vurur, ev sahibi kapıyı açınca da şöyle der.......... hatunun selamı var. ........ günü cehize bahmaya, ayn günü akşamı cehiz yazmaya, ...... günü gelin hamamina, hamamin olduğu akşam gina gecesine, ...... günüde gelin almaya gelecekmisssiniz hepinizi de bekliyorlar bak gelin ha hemi." derdi. Ev sahibi de okuyucu gezen bayana "Vah eylemi hayırh uğurlu olsun, Allah'tan bi mani keder çlkmazsa helbet (tabi ki) geliriz. Sağol anam sana da bir sürü zahmet oldu." diyerek doğal olarak samimiyet ve memnuniyetini ifade ederdi. Sonra ev sahibi de küçük kızın çantasına bahşiş verir bir takım ikramlarda bulunurdu. Bazen ayran veya șerbet, bazen de içeri alır onları dinlendirip, yemek ikraminda bulunurlardı. Sira ile bu şekilde evleri tek tek gezerler, Okuyucu Gezme (düğüne çağırma) görevini yerine getirirlerdi (Serin, 2012).
\end{abstract}

Yalnız bu davet etme işi herkese aynı şekilde yapılmazdı. Zira davetlilerin yakınlık durumu onların, düğünün bazı aşamalarına katılmalarını bazılarına ise katılmamalarını gerektirirdi. O bakımdan davetçinin selam kelamdan sonra ilettiği mesajlar farklılık arz ederdi (Boyraz, 2009: 88). Ayrıca okuntu sırasında davetlilerden toplanan bahşişler okuyucu ve küçük kız arasında paylaşlırdı. Okuyucular davetlerde veya düğünlerde küskünleri barıştırma işlevini de yerine getirerek toplumsal barışın devamlılığına katkıda bulunurlar. Zira bu kişiler bulundukları bölgenin kültürünü ve geleneğini iyi bilen ve uygulayan kişilerdir.

\title{
3. Kültürel ekonomik bir imge olarak okuntudan e-davetiyeye geçiş
}

Türk toplumunun sosyo-kültürel kodlarını taşıyan okuntu geleneği, yazılı kültür ortamının yaygınlaşmasıyla ilk olarak yerini düğün davetiye kartlarına bırakmaya başladı. Okuntu geleneğinin düğün sahibine maliyetini düşündüğümüzde bu geçiş bir noktada ekonomik nedenlerle gerçekleşmiştir. Bununla birlikte sanayileşmenin gelişmesi dolaysıyla kentleşmenin hızla artması, köy ve kentteki demografik yapının değişmesi, insanlar arasında ekonomik farkların belirginleşmesi, yazılı ve elektronik kültür ortamının çok hızlı bir şekilde yayılması buna bağlı olarak bireyler arasındaki iletişimin kolaylaşması, üretim ve tüketim dengelerinin değişmesi gibi etkenler de okuntu geleneğinden davetiyeye geçişi sağlamıştır.

Davetiyelerin ortaya çıkışıyla okuntu geleneğinde kumaş, çorap, şeker gibi hediyelerin verilmesi ortadan kalkmıştır. Nebi Özdemir'in de vurguladığı gibi geleneksel kültürde "hediyeleşme, sosyal bă̆ yaratan, kültürü yaşatan ve aktaran, farklılaştıran bir ara sistem olarak işlev görmüştür" (Özdemir, 2008b: 469). Davetiyeler bu işlevi yüklenmeye çalışarak toplumda yerini almıştır. Söz ile ifade edilen davet cümlelerinin yerini davetiyelerdeki "Düğün törenimizde sizleri aramızda görmekten mutluluk duyarız" şeklinde klişeleşmiş ve resmi bir tavırla yazılar almıştır. Ayrıca "bu davetiye iki kişiliktir" uyarıları da ilerleyen dönemlerde kartlarda yerini almıştır. Bununla birlikte toplumun geçiş evresi olan düğünlerden çocuklar uzaklaştırılarak geleneğin kuşaktan kuşağa aktarımı da kesintiye uğramıştır. Kentte yapılan düğünlerin ekonomik olarak pahalıya mal olması, şehir ortamında okuyucu bulunmaması veya şehrin buna uygun olmaması bu olguyu ortaya çıkaran ana etkenlerdir. Okuntu geleneğinde ise bu durum söz konusu değildir, tek ölçü kaç kişi olursa olsun düğüne gidilmesidir. Ancak okuntu geleneğinde kişiye göre değissen davet cümleleri ve dügünün belli aşamalarına katılma durumundan ötürü bireyler arasında 
eşitsizlikler ortaya çıkıyordu. Bu nedenle kişiler arasında alınganlıklar, küslükler ve dargınlıklar oluşuyordu. Davetiye kartlarıyla bu durum ortadan kalkarak herkese standart bir davet mesajı gönderilmeye başlanmıştır.

Kentte yapılan düğünlerde davetiyeler olmazsa olmazlar arasındadır. Bu nedenle hemen hemen her semtte bir tane davetiye dükkânına rastlamak mümkündür. Tanınmış, güler yüzlü, tatlı dilli okuyucuların yerini ticari markalar almıştır. Böylelikle kâğıtçıdan matbaaya, tasarımcıdan satıcıya kadar geniş bir ekonomik alan oluşmuştur. Türkiye'de 2012 yllında 600 bin (sabah, 2012), TÜİK (2019) verilerine göre 2015 yllında 602 bin 9822016 yllında ise 594 bin 493 çift evlenmiştir. Örneğin her düğün için en az 300 davetiye bastırıldığını varsayarsak toplamda 180 bin davetiye yapar. Bin davetiye ortalama 350 TL'ye satılmaktadır. Yıllık olarak hesapladığımızda 180.000 x $350=63.000 .000$ TL gibi büyük hacimli bir ekonomik alan oluşturur. Bütün bunlar da gösteriyor ki okuntu geleneğinden davetiyeye geçiş ciddi bir kültürel ekonomik alan yaratmıştır.

İnsanların ekonomik durumları ve estetik anlayışlarına göre seçilen davetiye kartlarının şekil ve içerik özelliklerini hem Şeref Boyraz'ın (2009) görüşlerinden hem de elimizde bulunan yaklaşık bin adet davetiye kartından hareketle özetleyeceğiz. Davetiye kartları eski tarihli olanları kalp, gül, gelin-damat, güvercin gibi resimlerle süslenmiş, son beş yll içerisindekiler çiçek, kalp gibi çeşitli grafiklerle süslenmiş ya da gelin ve damadın isimleri yazılmıştır, bunlar eski tarihli olanlara göre hem kâğıt kalitesi hem de görsellik bakımından biraz daha gelişmiştir. Bununla birlikte düğün sahibi ailenin sosyal statüsü ve ekonomik durumları da davetiye kartlarına yansımıştır. Örneğin elimizde bulunan kartlardan Çırağan Sarayı ya da Dedeman Oteli gibi lüks mekânlarda yapılacak düğün davetiyeleri görünüş bakımından hemen fark edilmektedir. Bu davetiyelerin içeriklerinde "Beraberliğe adım atacakları bu mutlu günlerinde sizlerle olmaktan onur duyacaklar" biçiminde yazılmış resmi bir üslup vardır. Önceleri damadın evi olan düğün yerleri, sonraları değişiklik göstererek düğün salonu adı verilen mekânları ortaya çıkarır. Eski dönemlerde düğünler evlerde, konaklarda veya toplumun ortak kullandığı mekânlarda para verilmeden gerçekleşirdi. Daha sonraları dügünler düğün salonlarında bir ücret ödenerek yapılmaya başlandı. Dügün salonları başlangıçta ekonomik zenginliğin bir ifadesi olarak da algılanmıştır. Çünkü herkes sınırlı olan düğün bütçesini aşıp bu mekânlarda düğün yapamazdı. Genel olarak davetiyelerin üst kısmında evlenecek kişilerin isimleri, orta kısımda mesaj, alt kısımda anne ve babaların isimleri, onlarında altında yer ve tarih gibi diğer bilgiler yer almaktadır. Davetiyelerin en eski örneklerinde sadece gelin ve damadın babalarının adlarına yer verildiğini görüyoruz. Davetiyelerden değişimini izlediğimiz bir başka olgu da annelerin isimlerinin yazılmaya başlanmasıdır. Günümüze doğru gelindiğinde davetiyelerde annelerin adları da yer almaktadır. Bu durum, kadının toplumsal ve sosyal yaşamda statüsünün değiştiğinin de göstergesidir. Kitle iletişim araçları geliştikçe insanlar klasik davetiye biçimlerinin dışında farklılıklar aramaktadırlar. Elimizdeki davetiye kartlarına bunların yansıdığını görüyoruz. 2006 yılında takvim yaprağı şeklinde hazırlanan davetiye kartı dönemine göre oldukça yeni ve farklı bir karttır. 2011 yılında mesleğe göre hazırlanan davetiyeler de özgünlük ifade etmektedir. Örneğin bir eczacı için ilaç kutusu şeklinde, gazeteci için gazete sayfası biçiminde hazırlanan davetiyeler bunun en güzel örnekleridir.

Bilgisayar, bilişim ve iletişim, son dönemdeki temsilcisiyle internet alanındaki icat ve gelişmelerle birlikte yaşamın bütün alanları gibi, kültür de sanallaşmaya, sanal ortamda yaratılmaya, yaşanmaya, yaşatılmaya, aktarılmaya, değiştirilmeye başlanmıştır (Özdemir, 2008a: 290). Toplumların genelde elektronik kültür ortamı özelde ise sanal kültür ortamına geçişleri yeni kültür ürünleri, araçları ve hizmetlerinin de ortaya çıkmasına neden olmuştur. Yirmi birinci yüzyılda kitleler arasındaki iletişim kolay ve hızlı bir şekilde sağlamaktadır. Sanal kültür ortamı da aynı hızda insanoğlunun hayatının 
ayrılmaz bir parçası haline gelmektedir. Bu durum okuntu geleneğini de etkilemiştir. Okuntu, sanal kültür ortamında ilk olarak "CD davetiyeler" biçiminde bir dönüşümle aktarılmıştır. CD davetiyelerin üzerinde gelin ve damadın birlikte olduğu bir fotoğraf yer alır. Fotoğrafın üst kısmında çiftin adı, alt kısımda ise düğünle ilgili bilgiler yer alır. CD’nin içeriği gelin ve damadın isteğine ve ellerindeki verilere göre değişiklik göstermektedir: Gelin-damat fotoğrafları, evlilik teklifi, kız isteme merasimi, nişan töreni, birbirlerine yazdıkları mektuplar, düğüne davet mesajları gibi. CD davetiyeler içerik olarak kartlardan daha zengindir. CD davetiyelerdeki zenginliği okuntu geleneğindeki hediye vermenin modern biçimine dönüşmüş hali olarak değerlendirebiliriz. Çünkü CD davetiyeler çiftin mutlu anılarını paylaştıkları bir hediye gibi algılanmakta ve davetiye kartları gibi atılmayıp saklanmaktadır. Bu davetiyeler kartlara göre oldukça pahalıdır. CD şeklindeki davetiyelerin adet fiyatı 2 ile 5 TL arasında değişiklik göstermektedir. Bir düğün için bin kişilik bir davetiye yaptırmak istediğinizde yaklaşık maliyeti 800 TL$^{3}$ yapmaktadır. Bu noktada yeni bir ekonomik istihdam alanı ortaya çıkmıştır. Bu fiyatlara animasyon tasarımı veya video tasarımı gibi ekstra ücretler yansıtılmaktadır. Önümüzdeki yıllarda CD davetiyelerin yaygınlı kazanması kaçınılmazdır. Bu bağlamda bu kültürel alan Türkiye'de yllık yaklaşık 900 milyonluk bütçeye sahip bir alan oluşturacaktır.

Düğün davetiyelerine sanal kültür ortamında da rastlamaktayız. Burada yazılı ya da elektronik bir araç kullanılmamakta ve ekonomik olarak herhangi bir ücret ödenmemektedir. Bu tip davetiyeler daha çok popüler sosyal iletişim ağı olan Facebook'ta yaygın olarak karşımıza çıkmıştır. Facebook’ta oluşturulan düğün daveti kullanıcılara etkinlik şeklinde gönderilir. Davet gönderilen kullanıcı da "katıl", "belki" ve "geri çevir" butonlarından herhangi birine tıklayarak düğüne katılıp katılmayacağının yanıtını verir. Ayrıca düğün etkinlik sayfasında, kişilerin evlenecek çift için iyi dilekleri yer alır ve kimlerin düğüne katılacağı kimlerin katılmayacağı da gösterilir. $\mathrm{Bu}$ davetlerin başlıkları "Evleniyoruz", "Zeynep\&Hüseyin... Düğün” gibi kullanıcıların istedikleri cümlelerden oluşur. Bu yönüyle yazllı kültür ortamının dügün davetiyeleri ile benzerlik gösterir. Davet edilen kişiye gönderilen iletide "Sevgiyle dolu birlikteliğimizi sonsuza taşıdığımız bu mutlu günümüzde sizleri de aramızda görmek dileğiyle...” gibi kalıplaşmış mesajlar yer alır. Daveti kabul eden veya etmeyen kullanıcı isterse etkinlik sayfasına gelindamat hakkındaki düşüncelerini de yazar. Gelin veya damat istediği kişiye özel bir mesaj atarak ya da sanal ortamda konuşarak düğününe bizzat davet de edebilmektedir. Bu yönüyle okuntu geleneğine en yakın davet biçimi sanal kültür ortamıdır. Sanal kültür ortamında yer alan davetiyelerin yani edavetiyelerin ekonomik anlamda dügün sahiplerine bir yükü yoktur. Bütün bu işlemler ücretsiz olarak yapılır. Etkinlik oluşturulduğu sayfada yer alan çeşitli firmaların reklamları ekonomik bir alan oluşturur. Ancak buradaki ekonomik alandan faydalanan sosyal ağ sahipleridir.

Birincil kültür ortamında icra edilen okuntu geleneğinden ikincil kültür ortamında yer alan davetiyelere geçişle birlikte ortaya pek çok farklılık çıkmıştır. Okuntu geleneğinde gösterge, mesaj, alıcı ve araç gibi unsurlar davetiye ve e-davetiyelerde değişmiş hatta bazı sinılılıklar oluşmuştur. Bu dönüşüm neticesinde değişen unsurları tablolaştıran Şeref Boyraz’ın (2009: 92) çalışmasına CD ve E-davetiyeyi ekleyerek genişlettik:

$3 \quad$ CD davetiyelerinin fiyatları şu şekildedir:

1-5 Adet Cd Düğün Davetiyesi = $5 \mathrm{TL}, 10$ Adet Cd Düğün Davetiyesi $=15 \mathrm{TL}$

50 Adet Cd Dügün Davetiyesi $=50 \mathrm{TL}, 100$ Adet Cd Düğün Davetiyesi $=90 \mathrm{TL}$

200 Adet Cd Düğün Davetiyesi = 170 TL , 300 Adet Cd Dügüun Davetiyesi = 260 TL

400 Adet Cd Düğün Davetiyesi $=350$ TL, 500 Adet Cd Dügün Davetiyesi $=440 \mathrm{TL}$

600 Adet Cd Düğün Davetiyesi = 530 TL , 700 Adet Cd Düğ̈̈n Davetiyesi = $620 \mathrm{TL}$

800 Adet Cd Dügüü Davetiyesi $=710$ TL, 1000 Adet Cd Dügüü Davetiyesi = 800 TL (ilanbir.com, 2012) 


\begin{tabular}{|c|c|c|c|c|c|}
\hline \multirow{2}{*}{ Dönem } & \multirow{2}{*}{ Kaynak/Verici } & \multicolumn{2}{|l|}{ İleti } & \multirow{2}{*}{ Araç/Kanal } & \multirow{2}{*}{ Alıcı } \\
\hline & & Gösterge & Mesaj & & \\
\hline Okuntu & $\begin{array}{l}\text { Ebeveynler, } \\
\text { özellikle babalar }\end{array}$ & $\begin{array}{l}\text { Elbiselik kumaş, } \\
\text { Havlu, mendil, } \\
\text { Çorap, ç̧erez, } \\
\text { şeker, vs. }\end{array}$ & $\begin{array}{l}\text { Falanca tarihlerde } \\
\text { düğ̈üümüz ve onların } \\
\text { şu şu aşamaları var. } \\
\text { Buyurun, gelin. }\end{array}$ & $\begin{array}{l}\text { Erkek, Kadın } \\
\text { ve çocuk } \\
\text { Törensel bir } \\
\text { havada }\end{array}$ & $\begin{array}{l}\text { Erkek, erkeğe } \\
\text { Kadın, } \\
\text { kadına }\end{array}$ \\
\hline Davetiye & $\begin{array}{l}\text { Önceleri baba, } \\
\text { sonra anne-baba, } \\
\text { daha sonra da } \\
\text { evlenen çiftler }\end{array}$ & $\begin{array}{l}\text { Ekonomik güç, } \\
\text { sosyal statü ve } \\
\text { estetik zevkin } \\
\text { belirlediği } \\
\text { davetiye kartı }\end{array}$ & $\begin{array}{l}\text { Falanca tarihlerde } \\
\text { düğünümüz ve onların } \\
\text { şu şu aşamaları var. } \\
\text { Buyurun, gelin. Fakat } \\
\text { aşamalarda eksilme } \\
\text { var }\end{array}$ & $\begin{array}{l}\text { Törensiz ve } \\
\text { genellikle } \\
\text { erkekler }\end{array}$ & Herkese \\
\hline $\mathrm{CD}$ & $\begin{array}{l}\text { Anne-baba çok az, } \\
\text { gelin-damat }\end{array}$ & $\begin{array}{l}\text { Fotoğraf basılı } \\
\text { CD }\end{array}$ & $\begin{array}{l}\text { Şu tarihteki } \\
\text { düğünümüze bekleriz. } \\
\text { Aşamalar çok az, ara } \\
\text { ara kına bilgisi var. }\end{array}$ & Törensiz, CD & Herkese \\
\hline $\begin{array}{l}\text { E- } \\
\text { davetiye }\end{array}$ & $\begin{array}{l}\text { Anne-baba yok, } \\
\text { gelin ve damat }\end{array}$ & İnternet sayfası & \begin{tabular}{lr} 
Şu & \multicolumn{2}{c}{ tarihteki } \\
düğünümüzde & sizleri \\
de & görmekten \\
mutluluk & duyarız. \\
Aşamalar & yok \\
derecesinde. &
\end{tabular} & $\begin{array}{l}\text { Törensiz, } \\
\text { internet }\end{array}$ & $\begin{array}{l}\text { Sosyal } \\
\text { paylaşım } \\
\text { sitesindeki } \\
\text { arkadaşlara }\end{array}$ \\
\hline
\end{tabular}

Tablo 1: Okuntudan E-davetiyeye geçişte değişen unsurlar

Henüz popülerlik kazanmamış olsa da sesli düğün davetiyeleri de sanal kültür ortamında yer almaktadır. Dügün sahipleri internet sitesi vasıtasıyla düğünleriyle ilgili bilgileri ister kendi sesleriyle ister başka birinin sesiyle sevdiklerinin telefonlarına sesli mesaj şeklinde iletiyorlar. Mesajı alan dinleyici sesli yönlendirmelerle düğüne katılıp katılmayacaklarını karşıya iletiyorlar. Gelin ve damada isterlerse sesli mesaj da birakabiliyorlar4.

\section{Sonuç}

Küreselleşme ve sanayileşmenin ortaya çıkardığı bilgi dünyasında bireyin, buna bağlı olarak da toplumun ekonomik ve kültürel değişim, dönüşüm ve güncellemeler yapması kaçınılmazdır. Kültürel kodlarımızı içerisinde barındıran okuntu geleneği bu bağlamda gerekli dönüşüm ve güncellemeleri yaşamıştır. Başlangıçta yazılı kültür ortamı, daha sonraları elektronik kültür ortamı davetiyeleri okuntu geleneğinin yerini almıştır. Bu yeni formlarla hem kültürel hem de ekonomik alanda varlığını devam ettirmiştir.

Okuntu geleneği, yazının kullanımının artması, okur-yazar sayısının çoğalması gibi nedenlerle ilk olarak yerini düğün davetiye kartlarına bırakmaya başladı. Okuntu geleneğinin hazırlık ve davet evrelerindeki maliyetlerin yükselmesi gibi ekonomik nedenler de bu geçişi sağlayan etkenlerdendir. Ayrıca nüfusun hızla kentte göç etmesi neticesinde demografik yapının değişmesi, sanayileşmenin yaygınlaşması, gelir dağılımında farkların oluşması gibi sebepler de bu geçişi bir nevi zorunlu kılmıştır. Okuntudan davetiye geçişle birlikte hediye verme geleneği ortadan kalmıştır. Okuyucu kişilerin de görevleri son bulduğu için

$4 \quad$ Sesli düğün davetiyelerin içeriği şöyledir: "Merhaba. Ben Engin, ben Melis evleniyoruz! Sevgili dostlarımız 25 Eylül Pazar günü saat 15:00’te Beşiktaş Evlendirme Dairesi’nde evleniyoruz. Davetiyeleriniz en kısa zamanda elinizde olacak. 25 Eylül Pazar günü saat 15:00’te nikahımıza katılmanız mümkün değilse lütfen 2'ye basınız. Şu anda karar veremedim biraz düşüneyim siz en iyisi beni bir hafta sonra arayın diyorsanız 3’e basınız. Bize sesli düğün mesajı bırakmak için lütfen 1'e basınız. Mesajı tekrar dinlemek için lütfen 4'e basınız. 25 Eylül'de görüşmek üzere, iyi günler (seslidugundavetiyesi.com, 2012)." 
toplumsal huzuru sağlama misyonları da yok olmuştur. Okuyucuların yerini ticari markalar ve nesneler almıştır. Okuntu geleneğinin düğün sahiplerine maliyeti yerini davetiye vd. harcamalara bırakmıştır. Bununla birlikte yeni ama büyük bir ekonomik pazar oluşmuştur. Okuntu geleneğinde genellikle babanın adına yer verilirdi. Ancak davetiyelerde bir süre sonra annelerin de isimlerinin yazlmaya başlanması kadının toplumsal yapıdaki yerinin değiştiğinin bir göstergesidir. Ev, köy odası, harman gibi düğün mekânlarının dönüşerek yeni ticari mekânlar oluşturması da davetiyelerde karşımıza çıkar. Okuntu geleneğinin kaynak, gösterge, mesaj, araç ve alıcı bağlamında yüklendiği anlam davetiyede değişmiş hatta bazıları yok olmuştur. Sosyal ve kültürel kodların değişimleri/dönüşümleri, toplumun önemli bir geçiş evresi olan düğünlere davet için kullanılan davetiyelere yansımıştır. Davetiyeler, ekonomik kültürel bir alan yaratarak toplumda hızla yerini almıştır.

Teknolojinin gelişmesine paralel olarak davetiye de kendi içerisinde bir dönüşüm yaşamaktadır. Davetiye kartlarından CD davetiye, CD davetiyeden internet davetiyelerine (e-davetiye) geçiş bu dönüşümün elbette ki son noktası olmayacaktır. Teknolojinin evrimi geliştikçe okuntu geleneğinin hangi noktalara doğru ilerleyeceğini ve nasıl bir kültür ekonomisi yaratacağını tahmin etmek oldukça güçtür.

\section{Kaynakça}

Adorno, T. W. ve M. Horkheimer. (2014). Aydınlanmanın Diyalektiği. İstanbul: Kabalcı Yayınevi.

Alptekin, A. B. (2009). Ceyhun'dan Ceyhan'a Evlenme İle İlgili Bazı Kavramlar (Kalın, Saçı, Okuntu, Aşerme, Toy) Üzerine. A.Ü. Türkiyat Araştırmaları Dergisi, 39, 307-321.

Arat, R. R. (2007). Kutadgu Bilig I Metin. Ankara: Türk Dil Kurumu Yayınları.

Atalay, B. (1999). Divanü Lûgat-it Türk Tercümesi III. Ankara: TDK Yayınevi.

Boyraz, Ş. (2009).“Okuntu”dan Davetiyeye Bir Dönüşümün Anatomisi. Millî Folklor Dergisi, S. 84, 8796.

Ercilasun, A. B. ve Z. Akkoyunlu. (2018). Dîvânu Lugâti’t-Türk: Giriş - Metin - Çeviri - Notlar - Dizin / Kaşgarlı Mahmud. Ankara: Türk Dil Kurumu Yayınları.

Ergin, M. (2008). Dede Korkut Kitabı-I. Ankara: TDK Yayınları.

Günay, E. (2010). Türkiye'de Kültür Ekonomisinin Gelişimi. Çerçeve Dergisi, S. 54, 8-13.

İncekara, A. ve E. Haykır Hobikoğlu. (2011). Kültür Ekonomisi Kapsamında Kültür Sektörlerinin Türkiye'de Gelişim ve Yansımaları. www.iav.org.tr/dosyalar/Kultur-Ekonomisi.doc, E. T. 28.12.2011.

Koşay, H. Z. (1944). Türkiye Türk Düğünleri Üzerine Mukayeseli Malzeme. Ankara: y.y..

Ögel, B. (2003). Türk Mitolojisi. Ankara: Türk Tarih Kurumu Yayınları.

Özdemir, N. (2008a). Medya Kültür ve Edebiyat. Ankara: Grafiker Yayınları.

Özdemir, N. (2008b). Türk Hediyeleşme Geleneği ve Medya. Uluslararası Sosyal Araştırmalar Dergisi, V. $1 / 4,467-480$.

Özdemir, N. (2009). Kültür Ekonomisi ve Endüstrileri ile Kültürel Miras Yönetimi İlişkisi. Millı̂ Folklor Dergisi, (84), 73-86.

Serin, S. (2012). Sivas'ta Okuyucu Gezme Geleneği. http://www. yigidolar.com/popup/haberyazdir.asp?haber=1883, E. T. 10.01.2012.

Turhan, M. (1969). Kültür Değişmeleri: Sosyal Psikoloji Bakımından Bir Tetkik. İstanbul: MEB Yayınevi.

Uçkan, Ö. (2009). Kent Ekonomisi, Kümelenme Stratejileri ve Kültür Endüstrileri: Politika Gerekleri. Avrupa ve Türkiye'de Kültür Politikalarn Kongresi. İstanbul.

Urfalı, A. (2012). Davet, Okuntu ve Okuntucu Dudu. http://www.emirdag.gen.tr, E. T. 08.01.2012. 
Yanıklar, C. (2010). Tüketim Kültürü, Kapitalizm ve İnsan İhtiyaçları Arasındaki İlişki Üzerine Bir Tartışma. C. Ü. Sosyal Bilimler Dergisi. C. 34, S. 1, 25-32.

\section{E-Kaynaklar}

http://www.avsarobasi.com/component/content/article/68/244.html, E. T. 03. 01. 2012.

http://www.cddavetiye.com/tr/product.php?id_product=501, E. T. 09. 01. 2012.

https://www.gov.uk/government/statistics/dcms-sectors-economic-estimates-2016-gva, E.T. 01.15.2019

http://www.ilanbir.com/cd-davetiye-davetiye-nikah-sekeri-kina-keseleri/, E. T. 10. 01. 2012.

http://www.sabah.com.tr/Ekonomi/2010/o7/25/yilda_6oo_bin_dugun_cezbetti_abdli_davids_br idal_turkiyeye_giriyor, E. T. 12.01.2012.

http://www.seslidugundavetiye.com, E. T. 25.06.2012.

https://www.tuik.gov.tr\%2FPdfGetir.do\%3Fid\%3D24642\&usg=AOvVaw2DWrMBoioXYnI1gSoBCr $7 w$ E.T. 25.04.2019 


\section{EK-DAVETIYELER}

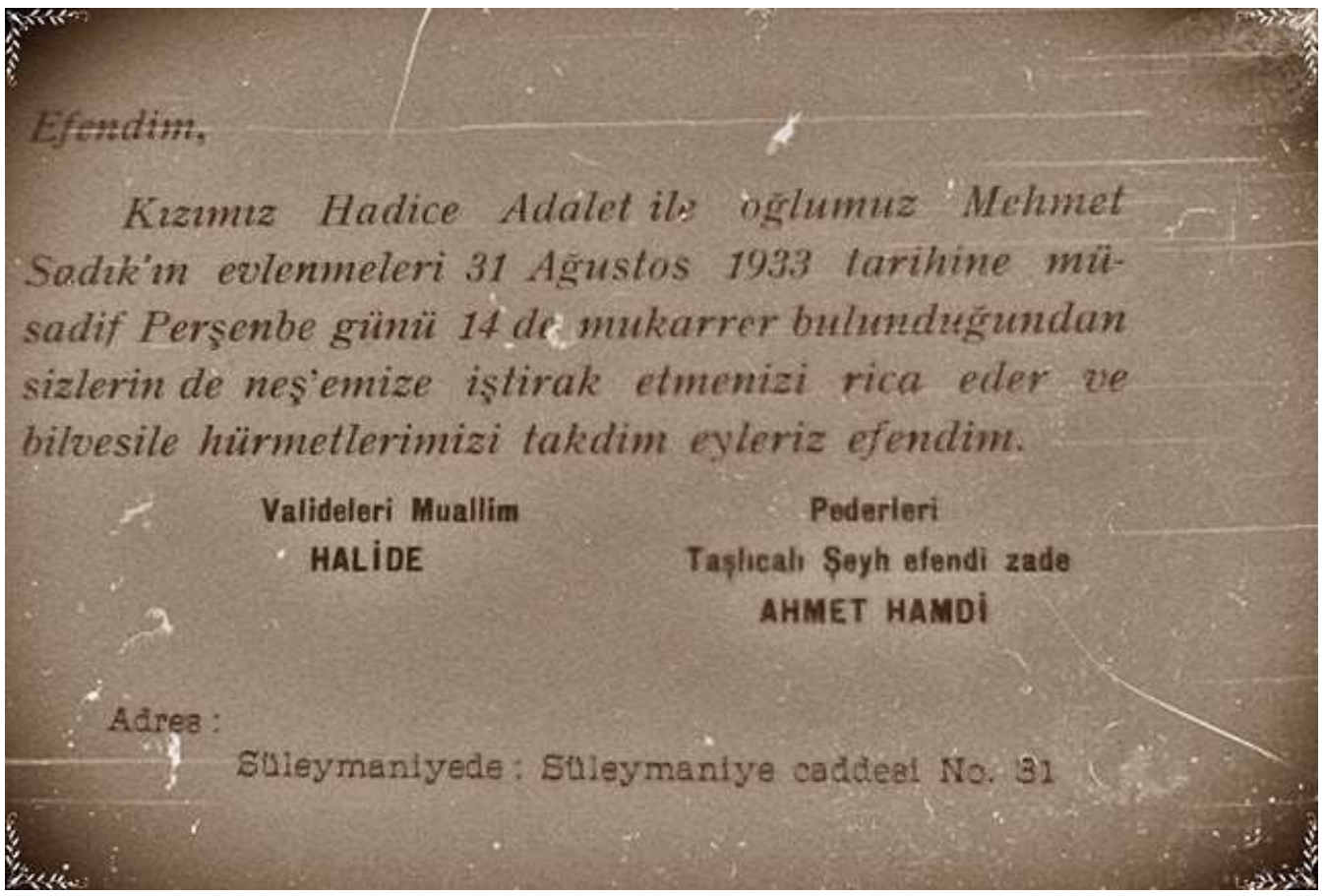

Resim 1: Eski bir davetiye örneği.

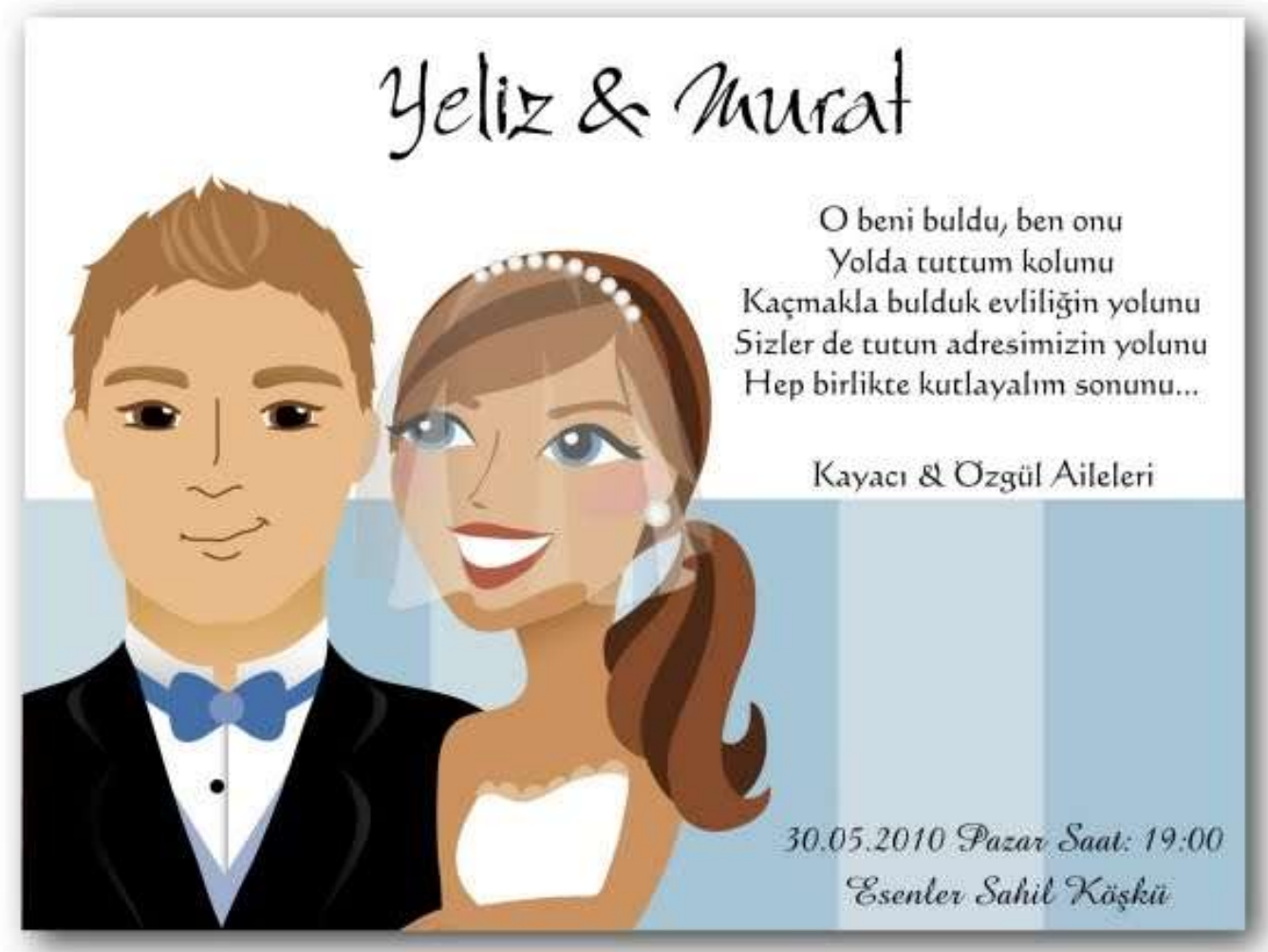

Resim 2: 21. Yüzyll davetiye örneği. 


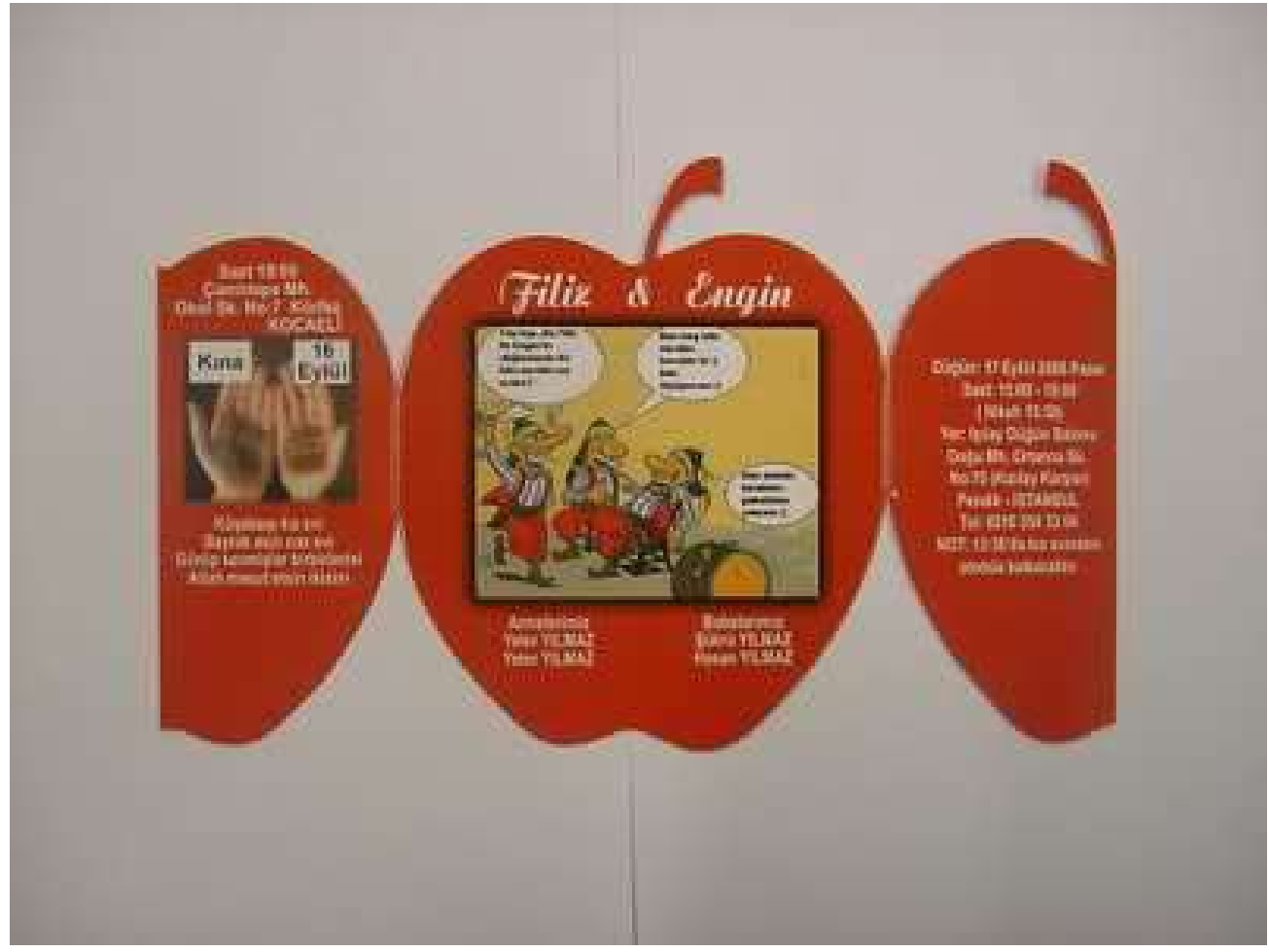

Resim 3: Farklı bir davetiye örneği.

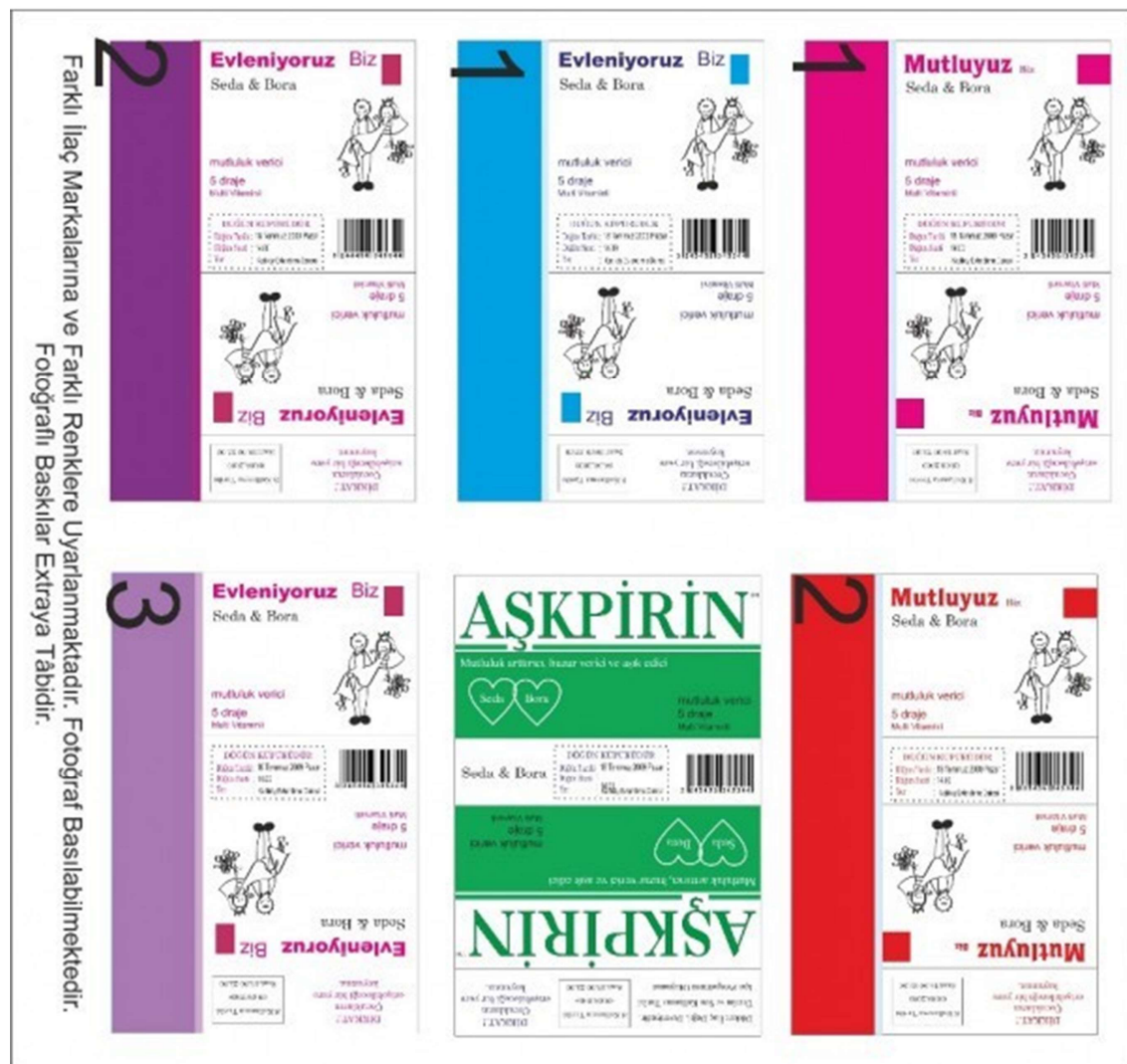

Resim 4: Mesleğe göre davetiye örneği. 


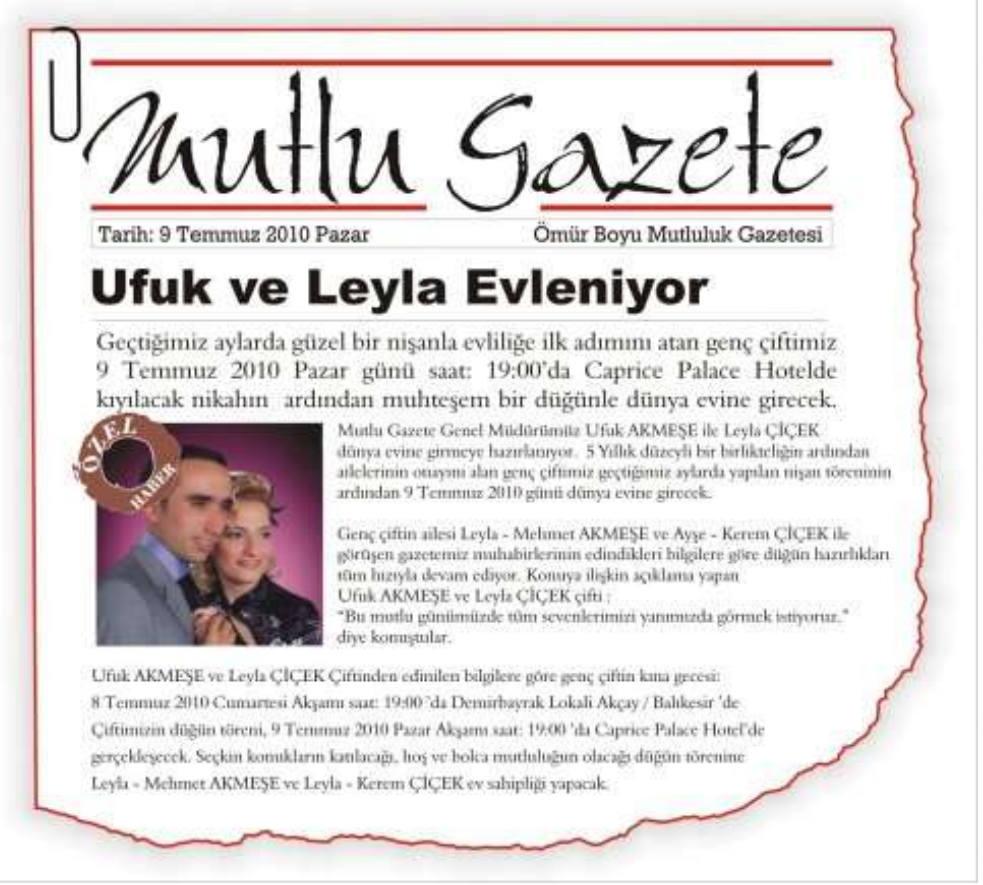

Resim 5: Mesleğe göre davetiye

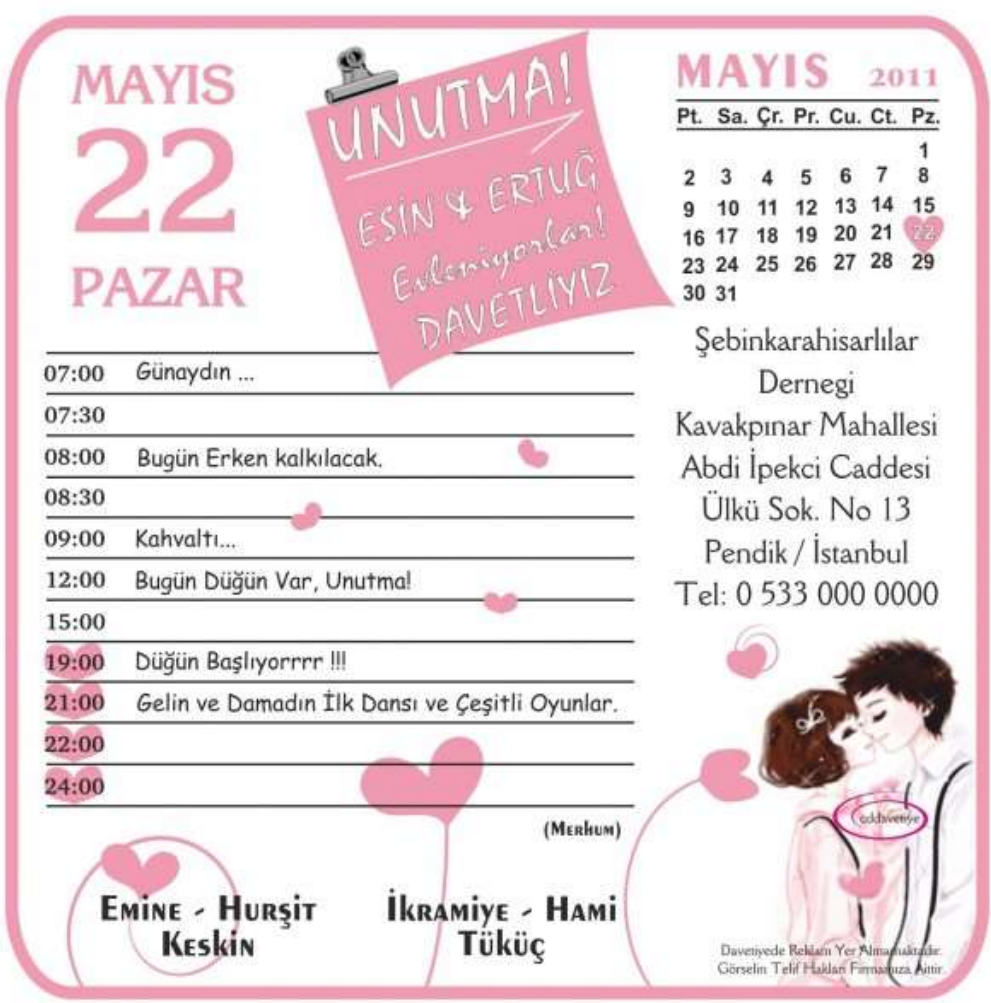

Resim 6: Takvim yaprağı şeklinde tasarlanmış davetiye örneği. 


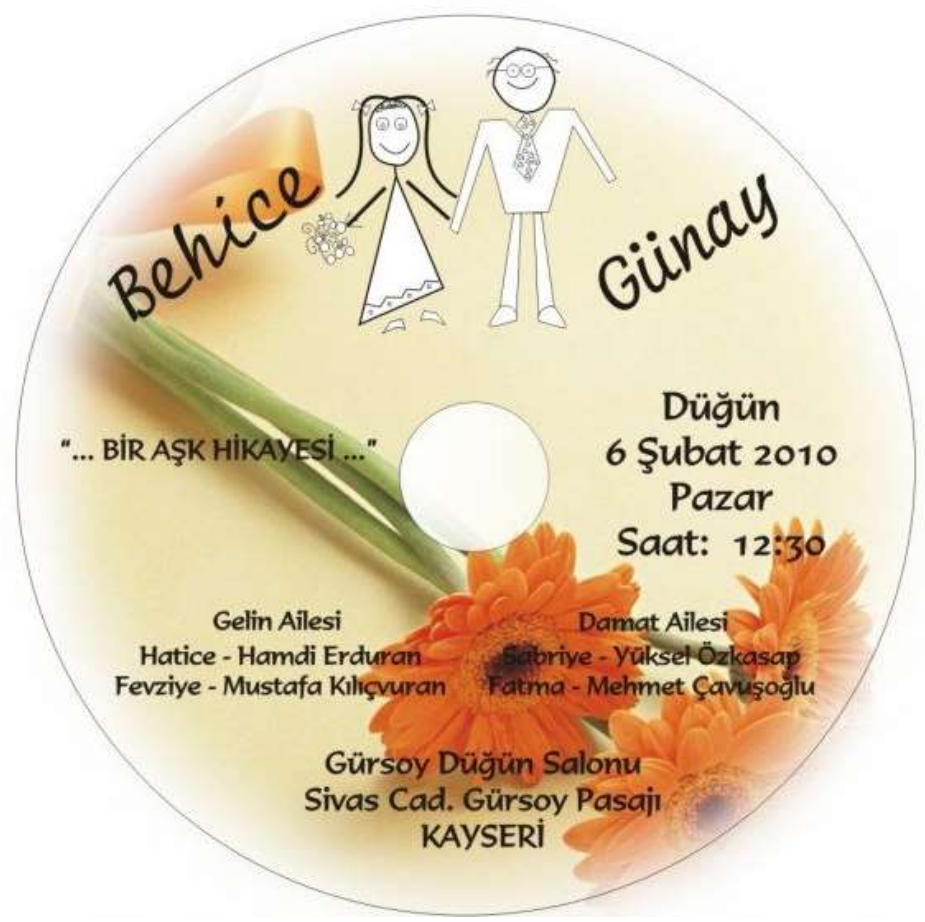

Resim 7: CD davetiye örneği

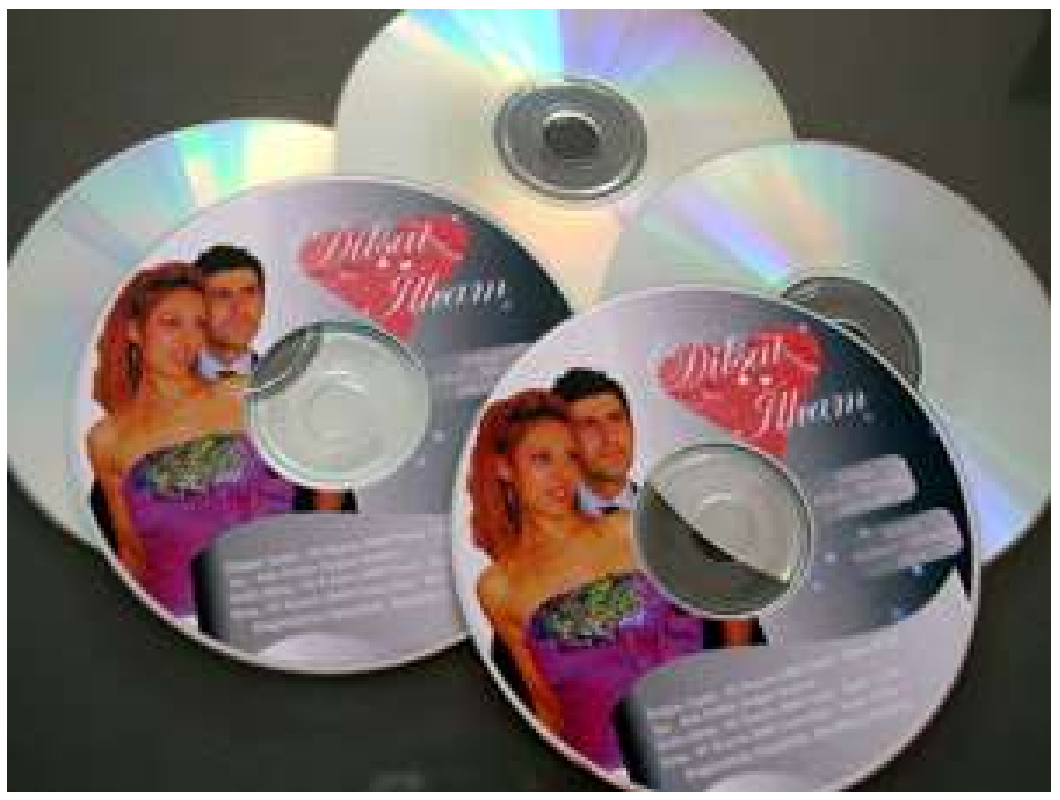

Resim 8: CD davetiye örneği-2 
facebook $\&$ arama a

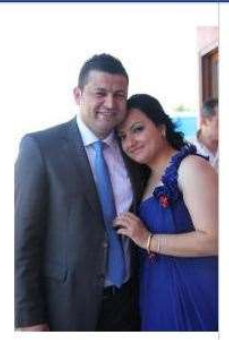

Zeynep \& Hüseyin ..... Düğün .....

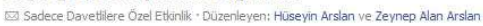

IIII 16 Ebim 2011 Pazar $\odot$ 13:00- 17:00
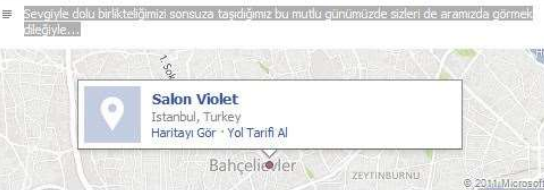

Gidenler (86)

P. ibrahim Gümüs

7id Zeynep Alan Arslan

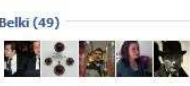

Davetilier (284)

10. Fissevin Akar

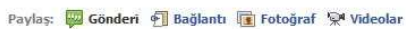

Bir seyler yaz...

Ayșegül Seven Divrikl

Canim mutuluugunuz $h$ he

Elif Nazan Özalp

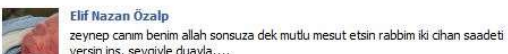

Beğen - Yorum Yap - 15 Ekim 2011, 10:41

7. 7 Z Zeliha Gedikoğtu

Zeliha Gedikoğlu
ömür boyu bir hayat paylasmannz dileğyle mutuluklar dilerin

.

Resim 9: Sanal kültür ortamı davetiye örneği. 